\title{
Bentuk-Bentuk Modernisasi Pertanian Studi Kasus Masyarakat Petani Di Desa Soki Kecamatan Belo Kabupaten Bima Nusa Tenggara Barat
}

\author{
Rostati $^{1)}$, Lutfin Haryanto ${ }^{2)}$,Jessy Parmawati Atmaja ${ }^{[3]}$ \\ ${ }^{1,2,3)}$ Sekolah Tinggi Keguruan dan Ilmu pendidikan Harapan Bima \\ Email: ${ }^{1)}$ tathysanggini3526@gmail.com_2) $\underline{\text { lutfin, }}$ 3) jessyparmawatiatmaja@habi.ac.id
}

\begin{abstract}
Agricultural modernization is a major change in agricultural patterns, namely from a traditional pattern (using various traditional methods) to a more advanced or modern pattern, which includes various aspects including; agricultural institutions and agricultural technology. The purpose of this study was to analyze the forms of agricultural modernization on farmers in Soki Village, Belo District, Bima Regency. The research method used is qualitative. The informants in this study were the farming community and the government in Soki Village. The data techniques in this study were observation, in-depth interviews, and documentation. The data validity used triangulation technique. The results showed forms of agricultural modernization in the farming community in Soki Village, from the paddy field processing stage to the post-harvest stage of rice and shallots, the farming community in Soki Village carried out agricultural activities using technological tools, but not all agricultural activities were carried out and used tools. agricultural technology because the farming community still understands traditional agricultural tools such as the habit of cutting rice, hoes for beating and leveling the land and planting the shallot method still doing the old or traditional
\end{abstract}

\section{Keywords: Modernization, agriculture, farming communities}

Abstrak. Modernisasi pertanian merupakan perubahan besar pada pola pertanian yaitu daripola tradisional (menggunakan berbagai cara tradisional) menuju pola yang lebih maju atau modern, dimana mencakup berbagai aspek yang meliputi; kelembagaan pertanian dan teknologi pertanian.Tujuan penelitian ini adalah menganalisis bentuk-bentuk modernisasi pertanian pada petani di Desa Soki Kecamatan Belo Kabupaten Bima. Metode penelitian yang digunakan adalah kualitatif. Informan dalam penelitian ini adalah masyarakat petani dan pemerintah di Desa Soki. Teknik pengumpulan data dalam penelitian ini adalah dengan observasi, wawancara mendalam, dan dokumentasi. Keabsahan data menggunakan teknik triangulasi. Hasil penelitian menunjukan Bentuk-bentuk modernisasi pertanian pada masyarakat petani di Desa Soki dari tahap pengolahan lahan sawah sampai pada tahap pasca panen padi dan bawang merah, mayarakat petani di Desa Soki melalukan aktivitas pertanian menggunakan alat teknologi pertanian, namun tidak semua kegiatan pertanian dilakukan dan menggunakan alat teknologi pertanian karena masyarakat petani masih mengadopsi alat-alat pertanian tradisional seperti sabit untuk memotong padi, cangkul untuk menggebur dan meratakan tanah serta cara penanaman bawang merah masih melakukan dengan cara yang lama atau tradisional.

Kata Kunci:Modernisasi, pertanian, masyarakat petani

\section{PENDAHULUAN}

dan $\begin{array}{r}\text { Indonesia merupakan negara agraris } \\ \text { sebagian besar penduduknya }\end{array}$ bermatapencaharian di bidang pertanian (Sariyeksi, 2014). Pertanian merupakan suatu usaha manusia untuk memperbaiki keadaan dan memenuhi kebutuhan hidup melalui kehidupan tumbuhan dan hewan (Pangesti
2015). Banyaknya penduduk atau tenaga kerja yang hidup atau bekerja pada sektor pertanian mengakibatkan pertanian sangat penting dari keseluruhan perekonomian nasional (Isnaini, 2017).

Sektor pertanian merupakan bagian dari sumber daya pembangunan potensialyang dimana sektor tersebut dapat dijadikan 
sebagai sektor strategis perencanaan pembangunan untuk masa sekarang maupun masa depan, baik di tingkat nasional maupun di tingkat daerah (Anugrah \& Ma'mun, 2003).Peranan sektor pertanian dalam pembangunan ekonomi sangat penting, karena sebagian besar anggota masyarakat Indonesia menggantungkan hidupnya pada sektor tersebut (Arsyad, 2010). Pertambahan jumlah penduduk yang cukup besar dan alat-alat teknologi pertanian seperti mesin traktor dan mesin diesel yang terus berkembang, baik jumlah maupun pengetahuannya sektor pertanian diharapkan dapat memenuhi kebutuhan pangan yang cukup besar dan terus berkembang dalam jumlah keragaman dan mutunya (Muspiroh, 2012).

Sektor pertanian dan sektor non pertanian secara bersama-sama dapat bekerjasama atau bersinergi dalam berbagai kegiatan pembangunan terutama dalam kegiatan pertanian (Hardati 2013).

Modernisasi di bidang sektor pertanian merupakan perubahan dari cara-cara tradisional menjadi cara-cara yang modern (Fatthaya, 2017). Perubahan-perubahan tersebut meliputi beberapa hal antara lain dalam pengelolahan tanah, penggunaan bibit unggul, penggunaan pupuk, penggunaan sarana-sarana produksi pertanian, dan pengaturan waktu panen (Munthe, 2007). Pengenalan terhadap cara-cara pertanian yang baru dilakukan untuk memperbaiki kelembagaan-kelembagaan yang berkaitan dengan pertanian, seperti: kelompok Tani, KUD, PPL dan sebagainya (Mahanani, 2003). Modernisasi sebagai sebuah perkembangan manusia dan masyarakat secara sosiologis dapat dianggap sebagai sebuah proses perubahan sosial. Soerjono Soekanto (2017) mengatakan bahwa perubahan sosial adalah segala perubahan pada lembaga-lembaga kemasyarakatan di dalam suatu masyarakat yang mempengaruhi aspek sosial, budaya,ekonomi, teknologi, maupun ilmupengetahuan serta sikap-sikap dan pola-pola perilaku di antara kelompokkelompok masyarakat (Gunawan, 2015).

Perubahan itu pada dasarnya adalah gerak perkembangan dari kehidupan tradisional menuju kehidupan yang modern. Perubahan yang terjadi pada masyarakat modern didorong oleh keinginan manusia untuk maju dan berkembang seiring dengan perubahan zaman (Nawir, 2013). Perubahanperubahan sosial petani akibat dari modernisasi adalah dengandiperkenalkannya mesin-mesin seperti mesin penuai, dan traktor tangan (Rifkian 2017).

Perkembangan masyarakat tradisional menuju masyarakat modern ditandai dengan kemajuan dalam bidang ilmu pengetahuan dan teknologi, seperti perubahan pada dari tata cara bertani dari alat pertanian manual atau tenaga manusia yang beralih ke tenaga mesin seperti pengolahan lahan pertanian biasa mengolah lahan menggunakan tenaga hewan sehingga beralih ke tenaga mesin/traktor.

Beranjak dari permasalahan di atas, peneliti tertarik untuk melakukan penelitian secara lebih mendalam mengenai bentukbentuk modernisasi pertanian pada masyarakat petani di Desa Soki, Kecamatan Belo, Kabupaten Bima, Nusa Tenggara Barat.

Tujuan penelitian ini adalah untuk menganalisis bentuk-bentuk modernisasi pertanianpada petani di Desa Soki, Kecamatan Belo, Kabupaten Bima,Nusa Tenggara Barat.

Modernisasi merupakan suatu proses transformasi dari suatu arah perubahan ke arah yang lebih maju atau meningkat dalam berbagai aspek dalam kehidupan masyarakat. Secara sederhana dapat dikatakan bahwa modernisasi adalah proses perubahan dari cara-cara tradisional ke cara-cara baru yang lebih maju yang bertujuan untuk meningkatkan kesejahteraan masyarakat. Modernisasi adalah suatu transformasi total kehidupan bersama yang tradisional atau pra moderen dalam arti teknologi serta organisasi sosial (Rosana, 2011).

\section{METODE PENELITIAN}

Penelitian ini menggunakan pendekatan kualitatif dengan studi kasus yang dilaksanakan di Desa Soki, Kecamatan Belo, Kabupaten Bima, Nusa Tenggara Barat. Lokasi penelitian berada di daerah bagian 
timur Kabupaten Bima didominasi oleh masyarakat yang bermata pencaharian sebagai petani, hal itulah yang mendasari peneliti menjadikan Desa Soki sebagai lokasi penelitian. Fokus penelitian dalam penelitian ini diantaranya tentang pengolahan lahan pertanian, penanaman tanaman, pemeliharaan dan pemanenaman serta pasca panen padi dan bawang merah yang dilakukan masyarakat petani di Desa Soki.

Penentuan tempat penelitian pada suatu wilayah penelitian sangat penting untuk dapat membantu menyederhanakan dan memfokuskan isu, terlebih pada saat masuk ke wilayah itu kita dengan pikiran terbuka serta tidak memiliki gagasan memecahkan masalah orang lain atau mengetahuinya sebelum memasuki wilayah tersebut.

Teknik pengumpulan data dilakukan dengan tiga cara, yaitu: wawancara mendalam, observasi dan dokumentasi. Wawancara mendalam dilakukan kepada informan yang berjumlah 32 orang, terdiri dari 15 orang di dusun satu, 15 orang di dusun 2, 1 orang aparat desa, dan 1 orang pihak dinas pertanian Kecamatan Belo. Observasi dilakukan dengan mengamati perilaku keseharian masyarakat petani, terutama tata cara penggunaan alat-alat pertanian, sedangkan dokumentasi dalam penelitian ini meliputi foto dan dokumendokumen yang dianggap penting.

Keabsahan data dilakukan dengan menggunakan triangulasi metodeTeknik analisis data yang digunakan dalam penelitian ini yaitu pengumpulan data, reduksi data, penyajian data, serta penarikan kesimpulan.

\section{PEMBAHASAN DAN HASIL}

\section{Bentuk Modernisasi Pertanian}

Modernisasi pertanian telah membawa perubahan-perubahan yang berarti pada masyarakat petani di Desa Soki. Hal ini dapat dilihat dari perubahan tata cara bertani dengan menggunakan alat teknologi pertanian seperti membajak sawah menggunakan mesin traktor, menyedot air dari sumur bor menggunakan mesin diesel untuk mengairi tanaman padi dan bawang merah, serta menggunakan mesin prontok padi, untuk mengetahui bentuk- bentuk perubahan tata cara pertanian masyarakat petani di Desa Soki lihat Tabel sebagai berikut.

Tabel. Bentuk Modernisasi Pertanian

\begin{tabular}{|c|c|c|c|c|c|}
\hline \multirow[t]{2}{*}{ No } & \multirow{2}{*}{$\begin{array}{c}\text { Tata cara } \\
\text { bertani }\end{array}$} & \multicolumn{2}{|c|}{ Padi } & \multicolumn{2}{|l|}{ Bawang Merah } \\
\hline & & Tradisional & Modern & Tradisional & Modern \\
\hline 1 & $\begin{array}{l}\text { Pengolah } \\
\text { an lahan }\end{array}$ & $\begin{array}{l}\text { Sapi, kerbau } \\
\text { dan Cangkul }\end{array}$ & $\begin{array}{l}\text { Mesin } \\
\text { traktor }\end{array}$ & $\begin{array}{ll}\text { Sapi dan } \\
\text { kerbau, } \\
\text { Cangkul }\end{array}$ & $\begin{array}{l}\text { Mesin } \\
\text { traktor }\end{array}$ \\
\hline 2 & $\begin{array}{l}\text { Penanam } \\
\text { an }\end{array}$ & $\begin{array}{l}\text { Menggunaka } \\
\mathrm{n} \text { tembilang }\end{array}$ & $\begin{array}{l}\text { Menanam } \\
\text { bibit yang } \\
\text { sudah } \\
\text { berumur 17- } \\
25 \text { hari }\end{array}$ & $\begin{array}{l}\text { menancapkan } \\
\text { bibit pada lahan } \\
\text { yang basah } \\
\text { menggunakan } \\
\text { tangan }\end{array}$ & $\begin{array}{l}\text { Tidak ada } \\
\text { perubahan }\end{array}$ \\
\hline 3 & $\begin{array}{l}\text { Pemelihar } \\
\text { aan }\end{array}$ & $\begin{array}{l}\text { Air hujan } \\
\text { Pupuk dari } \\
\text { kotoran } \\
\text { burung } \\
\text { Samprot } \\
\text { pompa }\end{array}$ & $\begin{array}{l}\text { Sumber air } \\
\text { dari sumur } \\
\text { bor } \\
\text { Pupuk } \\
\text { UREA } \\
\text { samprot } \\
\text { mesin }\end{array}$ & $\begin{array}{l}\text { Saluran irigasi } \\
\text { dari dam ncera, } \\
\text { Pupuk dari } \\
\text { kotoran burung, } \\
3 \text { botol } \\
\text { pestisida, } \\
\text { samprot pompa }\end{array}$ & $\begin{array}{l}\text { Sumber air } \\
\text { dari sumur } \\
\text { bor, pupuk } \\
\text { NPK, } \\
\text { UREA, } \\
\text { KCL, 5-15 } \\
\text { pestisida, } \\
\text { samprot } \\
\text { mesin }\end{array}$ \\
\hline 4 & $\begin{array}{l}\text { Pemanen } \\
\text { am }\end{array}$ & $\begin{array}{l}\text { Sabit dan } \\
\text { Gebotan }\end{array}$ & $\begin{array}{l}\text { Mesin } \\
\text { prontok }\end{array}$ & $\begin{array}{l}\text { Mencabut } \\
\text { menggunakan } \\
\text { tangan }\end{array}$ & $\begin{array}{l}\text { Tidak ada } \\
\text { perubahan }\end{array}$ \\
\hline 5 & $\begin{array}{l}\text { Pasca } \\
\text { panen }\end{array}$ & $\begin{array}{l}\text { Disimpan di } \\
\text { kolom } \\
\text { rumah }\end{array}$ & $\begin{array}{l}\text { Tidak ada } \\
\text { perubahan }\end{array}$ & Dijual langsung & $\begin{array}{l}\text { Dijual } \\
\text { langsung } \\
\text { dan di } \\
\text { simpan } \\
\text { untuk } \\
\text { ditanaman } \\
\text { kembali }\end{array}$ \\
\hline
\end{tabular}

Sumber: Rostati, 2019.

Perubahan-perubahan sosial petani akibat modernisasi adalah dengan diperkenalkan mesin-mesin, seperti penuai dan traktor tangan, yang telah menghilankan mata pencaharian penduduk yang selama ini mendapat upah dari menuai. Kemudian, pamakaian traktor tangan telah mengantikan kerbau, dari penggunaan samprot mesin menggantikan samprot pompa, menggatikan sabit dengan mesin pemotong padi, menggantikan alat perontok manual dengan mesin perontok, menggantikan pupuk-pupuk kandang dengan pupuk canggih lainnya baik itu dari olahan manusia maupun dengan olahan yang menggunakan bahan kimia.

Perubahan pada tata cara dan alat-alat pertanian pada masyarakat petani di Desa Soki dari sebagian kegiatan pertanian seperti pada tahap penanaman bawang merah, menggemburkan tanah serta pemaneman padi dan bawang merah masih mengadopsi teknik pertanian dan alat-alat pertanian yang tradisional.

\section{1) Pengolahan Lahan sawah}

Pengolahan lahan pertanian sebelum adanya teknologi pertanian seperti mesin traktor, masyarakat petani di Desa Soki, Kecamatan Belo, Kabupaten Bima membajak sawah menggunakan tenaga hewan, seiring 
dengan perkembangan teknologi di bidang pertanian masyarakat petani di Desa Soki sudah menggunakan mesin traktor untuk membajak lahan persawahan. Namun dengan berkembangnya mesin-mesin pertanian seperti mesin traktor masyarakat petani di Desa Soki masih menggunakan alat pertanian yang tradisional seperti cangkul dan tembilang.

Masyarakat petani di Desa Soki dalam pengolahan lahan untuk ditanamin padi tidak hanya menggunakan mesin traktor, namun menggunakan juga cangkul untuk meratakan tanah di pinggir area persawahan yang tidak bisa di bajak menggunakan mesin traktor.Masyarakat petani di Desa Soki selain menggunakan cangkul juga menggunakan alat pertanian yang tradisional yang lain seperti tembilang. Begitupun pada pembajakan lahan tanaman bawang merah, masyarakat petani di Desa Soki membajak lahan sawah tanaman bawang merah juga menggunakan mesin traktor, selain mesin traktor juga menggunakan alat pertanian yang tradisional seperti cangkul untuk membuat jarak sebelum penanaman bawang merah dilakukan atau dalam bahasa Bima maco lemba bawa.

Pengolahan lahan sawah terdapat persamaan hasil penelitian dengan hasil penelitian yang dilakukan Suyatno (2018) mengatakan bahwa penggunaan traktor untuk pengolahan tanah dapat meningkatkan produktivitas dan pendapatan usaha tani padi dan penggunaan traktor telah mengurangi penggunaan tenaga kerja sehingga dapat mempercepat kegiatan persiapan lahan dan penanaman.

\section{2). Penanaman}

Penanaman merupakan usaha penempatan benih atau menyebarkan biji diatas permukaan tanah atau menanamkan didalam tanah. Hal ini bertujuan untuk mendapatkan perkecambahan serta pertumbuhan biji yang baik. Kemampuan suatu benih untuk tumbuh setelah ditanam bergantung pada varietas benih, kondisi tanah dan air serta lingkungan hidupnya.

Kemajuan teknologi dan ilmu pengetahuan khususnya dalam bidang pertanian telah dikembangkan berbagi jenis mesin seperti mesin traktor, mesin diesel dan mesin perontok padi dimaksudkan untuk membantu masyarakat petani di Desa Soki, Kecamatan Belo, Kabupaten Bima dalam memudahkan proses penanaman, pemeliharaan serta pemaneman padi dan bawang merah sehingga dapat menghasilkan kinerja efektif dan efisien dengan keuntungan yang lebih besar pula.

Masyarakat petani di Desa Soki, Kecamatan Belo, Kabupaten Bima yang mayoritas masyarakat bertani padi dan bawang merah dan hidup di tengah-tengah kamajuan teknologi khususnya di bidang pertanian masih melakukan penanaman bibit padi dan bibit bawang merah secara manual/tradisional karena belum dikembangkan mesin penanaman padi dan bawang bawang merah dan masyarakat petani di Desa Soki melakukan penanaman penanaman pada waktu yang tepat supaya tidak mengalami gagal panen.

Penanaman benih padi terdapat persamaan hasil penelitian dengan hasil penelitian yang dilakukan oleh Pratiwi 2016, bahwa masyarakat petani harus melakukan penanaman pada saat yang tepat (waktu yang baik), apabila masyarakat petani tidak menanam pada saat yang tepat akan menderita kerugian.

\section{3) Pemeliharaan}

\section{a. Pengairan}

Pemeliharaan tanaman padi dilakukan setelah ditanam, pemeliharaan tanaman sebelum adanya teknologi pertanian, masyarakat petani di Desa Soki mendapatkan pengairan hanya mengandal air hujan untuk mengairi tanaman padi dan saluran irigasi dari Dam di luar Desa Soki untuk mengairi tanaman bawang merah.

Pemeliharaan tanaman padi dilakukan setelah ditanam, pemeliharaan tanaman sebelum adanya teknologi pertanian, masyarakat petani di Desa Soki mendapatkan pengairan hanya mengandal air hujan untuk mengairi tanaman padi dan saluran irigasi dari Dam di luar Desa Soki untuk mengairi tanaman bawang merah. Kemajuan teknologi pada bidang pertanian masyarakat petani di Desa Soki sudah tidak begitu memikirkan harus menunggu turun hujan dan membuat saluran irigasi dari Dam karena teknologi seperti mesin diesel akan menyedot air dalam sumur bor

\section{b. Pemupukkan dan Penyamprotan}


Pengendalian hama dan penyakit merupakan kegiatan rutin atau tindakan preventif yang dilakukan para petani di Desa Soki pada tanaman seperti tanaman padi dan bawang merah. Proses penyamprotan pengendalian hama dan penyakit pada tanaman sebelum adanya teknologi pertanian seperti mesin samprot, pupuk subsidi dan obat pestisida masyarakat petani di Desa Soki menyamprot dengan samprot manual atau samprot pompa dan dilakukan penyamprotan hanya 1-3 botol obat pestisida serta menggunakan pupuk organik atau pupuk kandang. Kondisi seperti inilah yang menyebabkan hasil tanaman masyarakat petani kurang maksimal dan mengganggu tingkat produksi tanaman padi dan bawang merah.

Kemajuan teknologi pada bidang pertanian dalam pemeliharaan tanaman padi dan bawang merah masyarakat petani di Desa Soki menggunakan alat pertanian yang lebih maju seperti mesin samprot dan menggunakan berbagai macam pilihan pestisida serta menggunakan pupuk seperti UREA, MPK dan merek lain-lain.

Pengendalian hama dan penyakit terdapat persamaan hasil penelitian dengan hasil penelitian yang dilakukan oleh Noer 2016, bahwa penggunaan pupuk subsidi dan pestisida serta luas lahan sangat mempengaruhi hasil pendapatan petani.

\section{4). Pemaneman}

Panen merupakan aktivitas pertanian atau kegiatan pemungutan hasil sawah atau ladang pada akhir dari budidaya tanaman (bercocok tanam) namun awal dari pasca panen. Kegiatan akhir dari budidaya tanaman padi dan bawang merah dilakukan secara berbeda-beda seperti yang dilakukan masyarakat petani di Desa Soki.

Pemaneman padi pada masyarakat petani di Desa Soki menggunakan alat manual seperti sabit untuk memotong padi dan gebotan atau dalam bahasa Bima kadego sebagai perontok padi. Namun seiring kemajuan teknologi pertanian masyarakat petani di Desa Soki merontok padi dari gebotan berkembang menjadi mesin perontok. Sedangkan pada pemaneman bawang merah masyarakat petani di Desa Soki masih melakukan cara yang lama.

Pemanenan bawang merah yang dilakukan masyarakat petani di Desa Soki dengan cara mencabut langsung menggunakan tangan namun terdapat dari tata cara pemaneman bawang merah yang dilakukan sebagian dari masyarakat petani di Desa Soki menggunakan tembilang yang kecil atau dalam bahasa Bima lumbi.

\section{5). Pasca panen}

Pasca panen merupakan tindakan penanganan, pengemasan, pemasaran serta penyimpanan hasil budidaya tanaman seperti hasil tanaman padi dan bawang merah yang dilakukan masyarakat petani di Desa Soki.

Masyarakat petani di Desa Soki dari hasil panen padi yang dimilikinya para petani menyimpan sendiri untuk kebutuhan makan sehari-hari dan cara menyimpannya masyarakat menyimpan di kolom bawah rumah hal ini tidak ada perbedaan dilakukan antara sebelum adanya teknologi pada bidang pertanian maupun setelah adanya kemajuan pada bidang pertanian.Pasca panen bawang merah masyarakat petani di Desa Soki dapat menjual langsung ke pedagang di lokasi persawahan miliknya karena bawang merah merupakan sumber pendapatan untuk kebutuhan rumah tangga dan biaya pendidikan anak, namun masyarakat petani di Desa Soki tidak menjual semua hasil pemaneman bawang merah miliknya karena masyarakat petani di Desa Soki menyimpan sendiri untuk ditanam kembali pada musim tanam selanjutnya.

\section{Analisis Hasil Penelitian Menggunakan Teori Modernisasi Wilbert E. Moore}

Modernisasi merupakan suatu proses transformasi dari suatu arah perubahan ke arah yang lebih maju atau meningkat dalam berbagai aspek dalam kehidupan masyarakat. Secara sederhana dapat dikatakan bahwa modernisasi adalah proses perubahan dari cara-cara tradisional ke cara-cara baru yang lebih maju, dimana dimaksudkan untuk meningkatkan kesejahteraan masyarakat. Seiring dengan pendapat Wilbert E. Moore 1950 yang mengemukakan bahwa modernisasi adalah suatu transformasi total kehidupan bersama yang tradisional atau pra moderen dalam arti teknologi serta organisasi sosial.

Perubahan yang terjadi pada masyarakat petani di Desa Soki menggunakan waktu yang cukup panjang, dari tata cara pertanian yang tradisional menuju tata cara pertanian yang modern, biasa mengolah 
sawahnya dengan menggunakan peralatan yang sangat sederhana dengan dibantu oleh tenaga hewan yang mereka pelihara.

Luas areal persawahanpun sangat terbatas oleh karena terbatasnya tenaga kerja serta lahan pertanian sehingga berdampak pula pada produktivitas yang hanya cukup untuk dikonsumsi dengan anggota keluarga sampai pada musim panen berikutnya (itupun kalau cukup). Seiring dengan kemajuan teknologi pada bidang pertanian masyarakat petani di Desa Soki pada pengolahan lahan pertanian sudah menggunakan tenaga mesin/traktor.

Persawahannya bertambah luas dengan alasan bahwa sudah ada alat yang dapat membantu pekerjaannya. Tingkat produktivitasnya juga bertambah, kalau sebelumnya hanya cukup untuk di konsumsi rumah tangga sampai panen berikutnya, sekarang justru telah terjadi surplussebahagian untuk konsumsisebahagian lagi untuk biaya pendidikan anak-anaknya dan biaya kesehatan.

Pasca panen padi terdapat perbedaan hasil penelitian dengan hasil penelitian Iswari (2012) mengatakan bahwah masalah dalam penerapan teknologipascapanen bukan berupa minimnyapenerapan teknologi oleh petani, tetapiberupa masalah nonteknis dan sosial.Waktu panen sering ditentukan oleh penderep yang jumlahnya melebihi jumlahidealnya sehingga gabah banyak yangtercecer. Selain itu, belum semua petanimampu dan mau menerapkan teknologipascapanen karena faktor kemampuandan budaya setempat.

\section{SIMPULAN}

Masyarakat petani di Desa Soki merupakan masyarakat yang menggantungkan hidupnya pada sektor pertanian, maka untuk memenuhi biaya hidupnya masyarakat petani di Desa Soki perlu ada kemajuan pada alatalat pertanian serta tata cara bertani pada tanaman padi dan bawang merah, dari alat dan tata cara pertanian yang tradisional seperti, pengolahan sawah menggunakan tenaga kerbau, menyamprot menggunakan samprot pompa, mengairi hanya mengandalkan air hujan serta menggunakan obat dan pupuk pestisida berkembang menggunakan alat dan tata cara yang modern.

Penggunaan alat pertanian yang modern yang dilakukan masyarakat petani di Desa Soki seperti mengolah lahan sawah padi dan bawang merah menggunakan mesin traktor, mengairi persawahan menyedot air dari sumur bor menggunakan mesin diesel, menggunakan obat dan pupuk subsidi MENYAMPROT menggunakan mesin samprot.

Bentuk-bentuk modernisasi pertanian pada masyarakat petani di Desa Soki dari tahap pengolahan lahan sawah sampai pada tahap pasca panen padi dan bawang merah, mayarakat petani di Desa Soki melalukan aktivitas pertanian menggunakan alat teknologi pertanian seperti mesin traktor, mesin diesel, mesin samprot serta mesin perontok padi, namun tidak semua kegiatan pertanian dilakukan dan menggunakan alat teknologi pertanian karena masyarakat petani masih mengadopsi alat-alat pertanian tradisional seperti cangkul, sabit dan tembilang.

\section{UCAPAN TERIMA KASIH}

Penulis menyadari artikel ini tidak dapat selesai tanpa doa, dukungan dan dorongan dari berbagai pihak. Pada kesempatan ini penulis ingin mengucapkan banyak terimakasih kepada ayahnda Bapak Ismail dan Ibunda Saodah yang senantiasan dan tiada henti-hentinya mendoakan penulis dan tidak lupa penulis mengucapkan banyak terima kasih pula kepada pemerintah Desa Soki dan masyarakat petani di Desa Soki yang telah meluangkan waktunya dalam memberikan informasi mengenai dampak dari modernisasi dalam involusi pertanian kepada penulis, sehingga penulis dapat menyelesaikan artikel ini sesuai dengan waktu yang ditentukan.

\section{DAFTAR PUSTAKA}

Anugrah, S.I. dan Ma'mun, D. (2003). Reorientasi Pembangunan Pertanian dalam Perspektif Pembangunan Wilayah dan Otonomi Daerah, Suatu 
Tinjauan Kritis untuk mencari Bentuk Perencanaan ke Depan. Jurnal Ekonomi dan Pembangunan, 2(2): 29-99

Arsyad, L. (2010). Ekonomi Pembangunan Edisi ke-5. Yogyakarta: UPP STIM YKPN

Daniel, Moehar. 2002. Pengantar Ekonomi Pertanian. Jakarta: PT. Buni Aksara.

Fattahaya. 2017. Modernisasi Pertanian Pada Petani Padi Di Kecamatan Bandar Baru Kabupaten Pidie Jaya.http://www.jim.unsyiah.ac.id

Gunawan Hanifah. 2015. Analisis Perubahan Sosial Budaya Masyarakat Cihideung Sebagai Tempat Wisata.ejournal.upi.edu

Hardati P. 2013. Pertumbuhan penduduk dan Struktur Lapangan Pekerjaan Di Jawa Tengah. Universitas Negeri Semarang.

https://journal.unnes.ac.id/nju/index. php/FIS

Hayami. 1981. Asian Village Economy at the Crossroad. Baltimore: John Hopkins University Press.

Isnaini Nurul Zuroidah. 2017. Analisis Fungsi Produksi Padi Di Kabupaten Malang. http://eprints.umm.ac.id

Iswari Kasma. 2012. Kesiapan Teknologi Panen Dan Pascapanen Padi Dalam Menekan Kehilangan Hasil Dan Meningkatkan Mutu Beras. Balai Pengkajian Teknologi Pertanian Sumatera

Barathttps://media.neliti.com

Johnson. 1986. Teori sosiologi klasik dan modern. Jilid 1. Pt gramedia : Jakarta.

Kadirman.2017. Mengoperasikan Alat Mesin Budidaya Tanaman, Pemeliharaan Tanaman, Dan Pasca Panen. Kementerian pendidikan dan kebudayaan direktorat jenderal guru dan tenaga kependidikan.

Mahanani Subekti. 2003. Keadilan Agraria Bagi Perempuan Tani. Jurnal Analisis Sosial. Vol 8 No 2. Hlm.7-8

Miles dan Huberman. 1992.Analisis data Kualitatif. (diterjemahkan Oleh
Tjetjep Rohedi Rosidi). Jakarta: Universitas Indonesia.

Mubyarto. 1989. Pengantar Ekonomi Pertanian. Lembaga Penelitian, Pendidikan dan Penerangan Ekonomi dan Sosial. Jakarta.

Munthe Marhaeni Hadriana. 2007. Modernisasi Dan Perubahan Sosial Masyarakat Dalam Pembangunan Pertanian: Suatu Tinjauan Sosiologis.http://repository.usu.ac.id Muspiroh Novianti. 2012. Peran Sektor Pertanian Dalam Memenuhi Kecukupan Pangan Nasional. Jurnal scientiae educatia volume 1 edisi 2. Https://www.syekhnurjati.ac.id/jurna l/index

Nawir Muhammad. 2013. Perubahan sosial masyarakat dari tradisional ke modern(studi kasus masyarakat di desa tosora kabupaten wajo). Fakultas fkip. Unsmuh.makassar. Https://www.academia.edu/8591102

Notohadiprawiro. 2006. Pengolahan Kesuburan Tanah Dan Peningkatan Efesiensi Pemupukkan. http://soil.faperta.ugm.ac.id/tj/1981/1 984\%20penge.pdf. Diakses tanggal 15 juni 2019

Noer Hasmari. 2016. Pengembangan Tanaman Bawang Merah Di Desa Bulupountu Jaya Kecamatan Sigi Biromaru Di Tinjau Dari Faktor Faktor Produksi. Sulawesi Tengah.Universitas Alkhairaat. https://media.neliti.com

Rifkian Enggal Bayu. 2017.Modernisasi Pertanian (Studi Kasus Tentang Peluang Kerjadan Pendapatan Petani Dalam Sistem Pertanian. https://jurnal.unei.ac.id

Rosana Ellya. 2011. Modernisasi dan perubahan sosial. http://ejournal.radenintan.ac.id

Sariyeski. 2014. Upaya Pemerintah Desa Dalam Menumbuhkan Gerakan Partisipasi Kelompok Tani UntukPemanfaatan Lahan Tidur. 
Terakreditasi Peringkat 5 (No. SK: 85/M/KPT/2020)

Universitas Pendidikan Indonesia.

http://repository.upi.edu

Soekanto Soerjono. 2007. Sosiologi Suatu

Pengantar. Jakarta : Rja Grafindo Persad

Suyatno Adi. 2018. Pengaruh Penggunaan Traktor Terhadap Pendapatan dan Penggunaan Tenaga Kerja pada Usahatani Padi di Kabupaten Sambas. Journal of Agribusinessand Rural Develpoment Research. https://media.neliti.com

Yanis. M. 2013. Pengaruh Teknologi Pertanian Terhadap Perubahan Sosial Masyarakat Petani Padi Sawah (Suatu Penelitian di Kemukiman Glee Yeung Kecamatan Kuta Cet Glie, Kabupaten aceh Besar). Banda Aceh: FSIP Unsyiah.

Pratiwi Ekan Lestari. 2016. Modernisasi Pertanian Dan Pengaruhnya Terhadap Sosial Ekonomi Petani Di Diy Tahun 1968-1984. Universitas Negeri Yogyakarta. http://journal.student.uny.ac.id 